\title{
A Látrányi Puszta Természetvédelmi Terület recésszárnyú-alkatú (Megaloptera, Raphidioptera, Neuroptera) faunája
}

\author{
ÁBRAHÁM LEVENTE \\ Somogy County Muscum, Natural History Department, \\ H-7400 Kaposvár Fö u.10., Hungary, e-mail: levi@smmi.hu
}

ÁвRAHÁM L.: The neuropterid fauna of the Látrányi Puszta Nature Conservation Area (Megaloptera, Raphidioptera, Neuroptera)

Abstract: In 1999 and 2001, the author carried out faunistical samplings in 6 different habitats of the protected area. Samplings were collected by light, portable light traps at night and by netting technique during the day. Altogether 434 specimens belonging to 1 Megaloptara, 1 Raphidioptera and 35 Neuroptera species were collected. The fauna of the xcrophil sandy grasslands proved to be the most significant. One protected species, Myrmeleon formicarius was found in the area.

Key words: Ncuroptcra, faunistic, nature conservation, Hungary

\section{Bevezetés}

A Látrányi Puszta Természetvédelmi Terület recésszárnyú-alkatú faunája az 1999-ben megindult alapfauna vizsgálatokig gyakorlatilag teljesen ismeretlen volt. Ez igaz a teljes gerinctelen faunára nézve is igaz volt.

A Somogy Megyei Múzeumok Természettudományi Osztályának gyűjteményében 7 fajról találtam adatokat, amelyeket az 1990 és 1994 között folytatott "Somogy megye természeti értékei" címü OTKA kutatási téma keretében alkalmi gyüjtésekből származtak. Ezek föleg a terület faunájára is jellemzö hangyaleső fajokra vonatkoztak. Közöttük a védett Myrmeleon formicarius is elökerült.

A rendszeres kutatómunkát 1999-ben a Duna-Dráva Nemzeti Park támogatásával kezdtem meg, majd 2001-ben a mintavételezéseket egy sikeres KAC pályázat anyagi támogatásával tovább folytathattam.

A Látrányi Puszta Természetvédelmi Területén történt kutatások célja a terület alapfauna feltárása és a természetvédelmi értékek területi elhelyezkedésének megállapítása volt, ami a terület kezelési tervének elkészitéséhez nyújtott információt.

\section{Anyag és módszer}

A természetvédelmi területen az elözetes terepbejárások alkalmával állandó mintavételi helyeket jelöltem ki úgy, hogy abban a védett terület minden élöhely típusa szerepeljen. Így vizsgáltam a (1) mocsár- és láprétek, (2) patakmenti füzesek, (3) vízi élöhelyek, 
(4) mezo-higrofil erdőfoltok, (5) xerofil homoki gyepek és (6) ültetett erdei fenyvesek recésszárnyú-alkatú közösségeit. Az állandó mintavételi helyeket az 1. ábrán jelöltem.

A mintavételezéseket elsősorban fü- és lombhálózással végeztem. Az éjszakai személyes lámpázások alkalmával $160 \mathrm{~W}$-os HGLI izzót és $20 \mathrm{~W}$-os ún. fekete fényü (black light) UV elektroncsövet használtam.

\section{Eredmények}

A Látrányi Puszta Természetvédelmi Területén a Neuropteroidea fauna természetvédelmi vizsgálata során 434 példány került elö; ez a mennyiség 35 faj között oszlik meg. 1 Megaloptera, 1 Raphidioptera, 32 Neuroptera fajt sikerült kimutatni.

\section{A fajok jegyzéke}

A fajlista összeállításához AsPöcK et al. (1980, 2001) munkáit használtam fel, a listában a mintavétel idejét, a fajok példányszámát valamint a nemét közlöm.

\author{
Megaloptera \\ Sialidae \\ Sialis lutaria (Linnacus, 1758) - 1999. 04. 30. \\ 10' 2000. 04. 29.3 ;

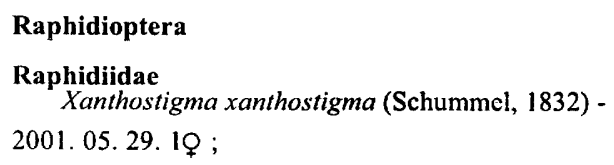

Neuroptera

Chrysopidae

Nineta flava (Scopoli, 1763) - 2001. 08. 08. 10

Chrysotropia ciliata (Wesmacl, 1841) - 1999. 04

30. $1 \sigma^{\prime}$ 1999. 05. 30. 30 2 \% 1999. 06. 02. 1\% ;

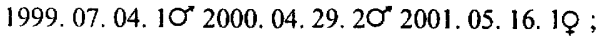

Chrysopa perla (Linnacus, 1758) - 1991. 06. 12 1 1 ; 1999. 04. 30. 1\% ; 1999. 05. 30. 10' 1\% ; 1999. 05. 30. $1 \sigma^{\circ} 8$ Q ; 1999. 06. 02. $20 \% 1 \%$; 1999. 06. 29. 2 2 ; 1999. 07. 16. 1ф ; 1999. 08. 03. 1 ; ; 2000.04.

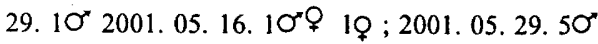
$7 Q ; 2001.07 .03 .2 \sigma^{\circ} 2001.07 .31 .2 \sigma^{*} 1$; ; 2001 08. 08. $1 \sigma^{\circ} 60 ; 2001.08 .16 .1 \sigma^{*}$

Chrysopa dorsalis Burmeister, 1839 - 2001. 08 08. 1 \% :

Chrysopa abbreviata Curtis, 1834 - 1990.06. 20. 1\% Chrysopa commata Kis ct Újhclyi, 1965 - 1991. 06. 12. $10 \sigma^{\prime \prime} 12 Q ; 1992.05 .27 .1 \%$; 1998. 06.07. $2 Q ; 1999.07 .31 .10 \% 2 Q$;

Chrysopa formosa Braucr, 1850 - 1999. 07. 16. 10 Chrysopa phyllochroma Wesmacl, 1841. 1999.07.31 10" 2001.07.0310
Chrysopa viridana Schneider, 1845 - 2000. 04.29. 10 Chrysopa nigricostata Braucr, 1850 - 2001. 05.

16. 1 \% ;

Chrysopa pallens (Rambur, 1838) - 2001. 05. 29. 10

Dichochrysa flavifrons (Braucr, 1850) - 1999

06. 29. 2 Q ;

Dichochrysa prasina (Burmeister, 1839) - 1999 06. 02. 3Q; 1999. 07. 04. 1Q; 2001. 05. 16. $7 \sigma^{\circ}$

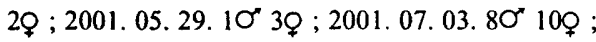
2001. 08. 08. 3\% 8\% ;

Dichochrysa ventralis (Curtis, 1834) - 1999. 06 02. 3 \% ; 2001. 05. 16. 1Q ; 2001. 08. 08. 60" 5\% ;

Chrysoperla carnea complex (Stcphens, 1836) 1990. 06. 20. 10 1999. 04. 30. 50 5\% ; 1999. 05

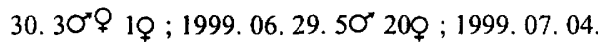
102 ; ; 1999. 07. 16. 2 ; ; 1999. 07. 31. 1 ; 2000. 04. 29. $4 \sigma 11$ \% ; 2001. 05. 16. 4O'2Q ; 2001. 05. 29.

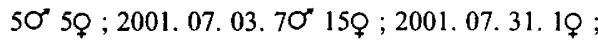

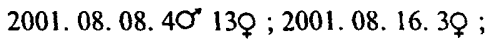

\section{Hemerobiidae}

Hemerobius humulinus Linnacus, 1758 - 1999. 04. 30. $2 \sigma^{\prime} 1999.06 .02 .10$; 1999. 06. 29. $2 \sigma^{\prime} 8$ \% ;

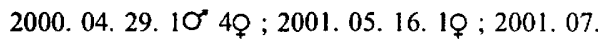
03. $1 \sigma^{\prime \prime} 1 \%$;

Hemerobius stigma Stcphens, 1836 - 2001. 08 08. 1ㅇ ;

Hemerobitus nitidultus Fabricius, 1777 - 1999. 06

29. 1 \% ; 2001. 08. 08. 1\% ;

Hemerobius micans Olivicr, 1792 - 2001. 07. 03. 1Q ; 


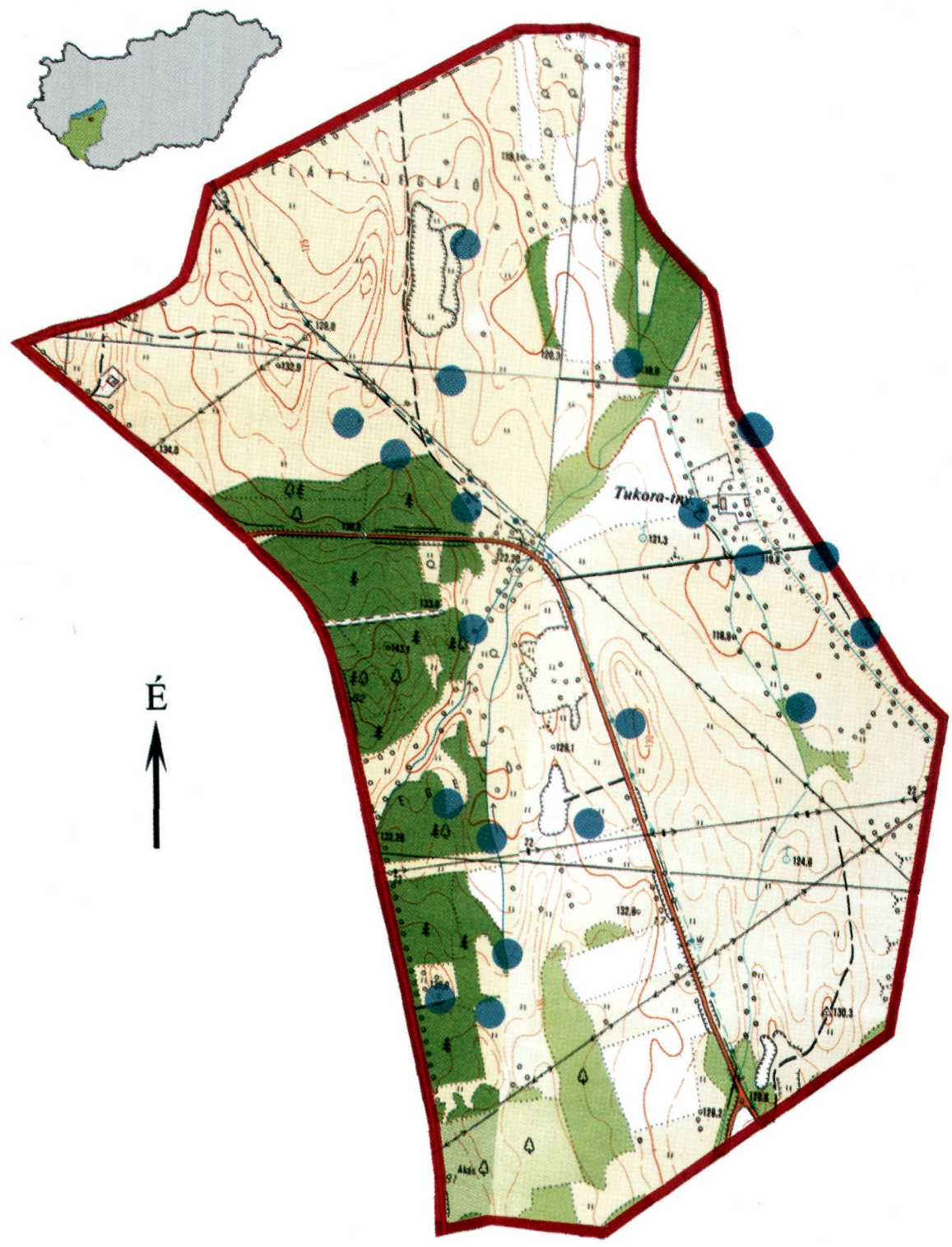




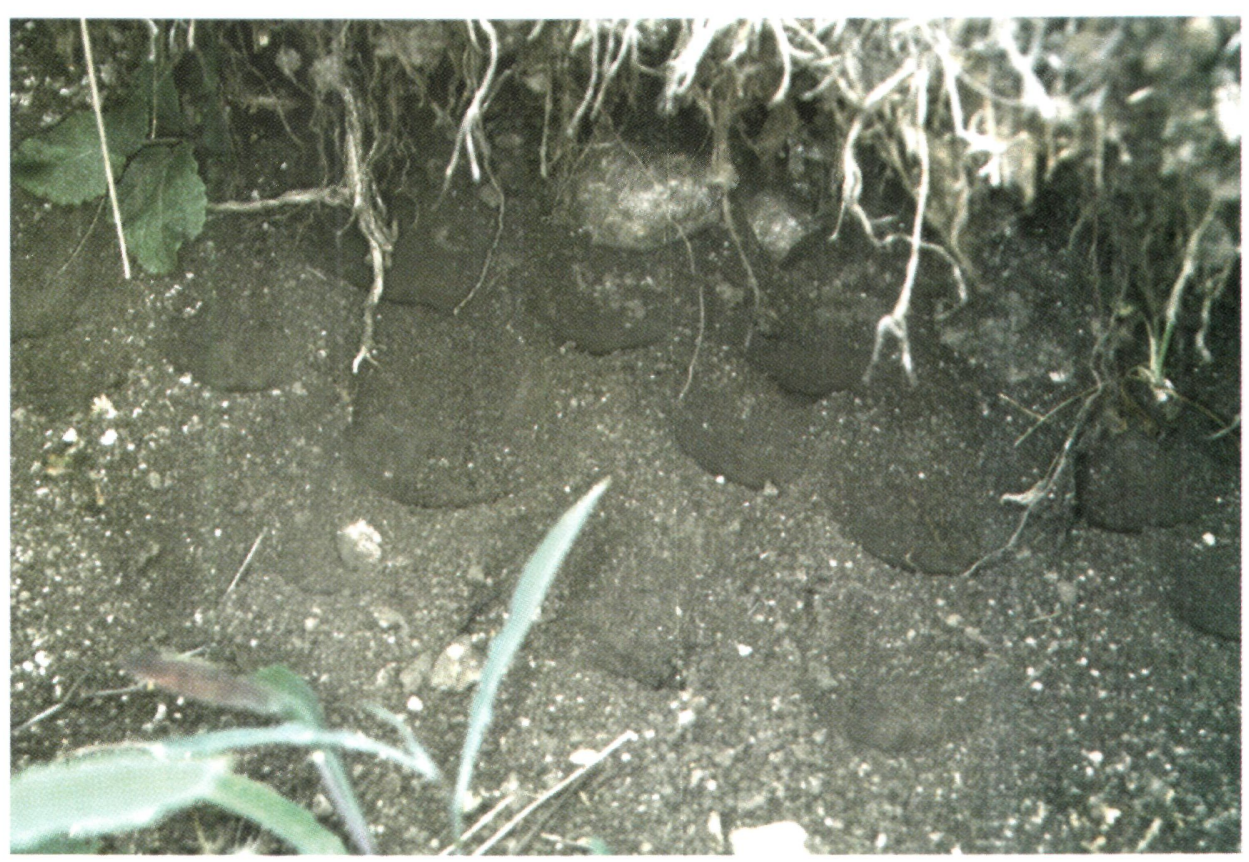

2. ábra: A védett területen a leggyakoribb hangyaleső faj az Euroleon nostras

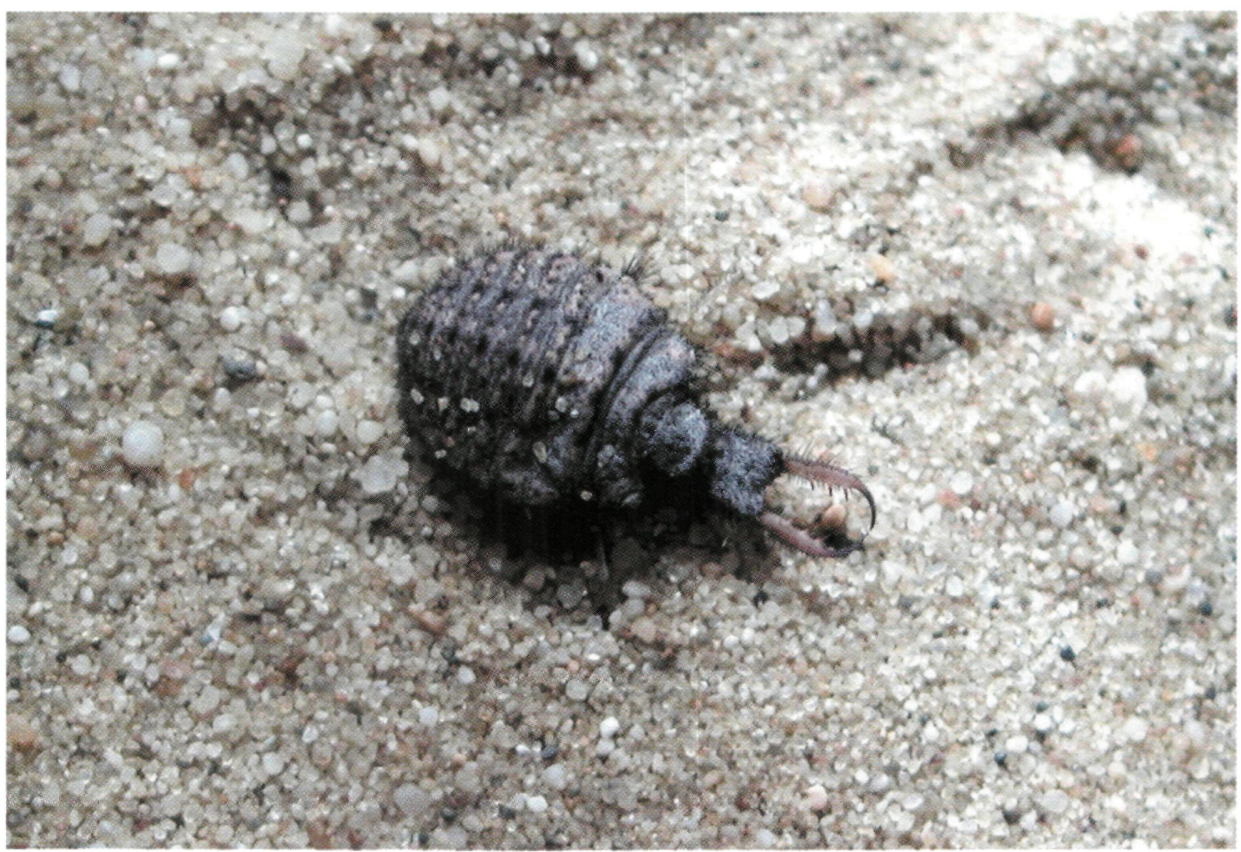

3. ábra: A Myrmeleon formicarius lárvája esốtól, széltól és direkt napsugárzástól védett mikrohabitatokban fejlődik 
Sympherobius pygmaeus (Rambur, 1842) - 2001.

05. 16. $2 \sigma^{\circ} 5$; ; 2001. 05. $291 \%$;

Micromus variegatus (Fabricius, 1793) - 1999.

06. 02. 10"1999.07. 16.1Q; 2001. 07.03.10

Micromus angulatus (Stephens, 1836) - 2001.

05. 29. $1 \sigma^{\prime \prime} 1$; 2001. 08. 08. 1申 ;

\section{Coniopterygidae}

Coniopteryx borealis Tjeder, 1930 - 2001. 05.

16. 10 2\% ; 2001. 05. 29. 2Q ;

Coniopteryx pygmaea Enderlein, 1906 - 1991.

06. 12. 4 ᄋ ; 2001. 05: 16.10"

Coniopteryx tineiformis Curtis, 1834 - 2001.05.

29. 2 Q ;

Coniopteryx haematica McLachlan, 1868 -

2001. 05. 16. 1Q ; 2001. 05. 29. 1Q ;

Coniopteryx esbenpeterseni Tjeder, 1930 - 1999.

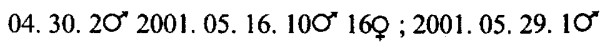

Conwentzia psociformis (Curtis, 1834) - 2001.

05. 16. 1\% ;

Semidalis aleyrodiformis (Stephens, 1836) -

1999. 04. 30. 1Q; 1999. 05. 30. 10Q ; 1999. 06. 29.

$30 ; 1999.07 .31 .1 \sigma^{\prime} 2000.04 .29 .2 \sigma^{\prime \prime} 1 \varnothing ; 2001$.

05. 16. $6 \sigma^{\prime \prime} 11$; 2001. 05. 29. 30'8\% ;

\section{Myrmeleontidae}

Myrmeleon formicarius Linnacus, 1767 - 1992.

04. 12. 1 lárva

Myrmeleon inconspicuus Rambur, 1842 - 1999.

04. 30.3 lárva; 1999. 06. 29. 3 lárva

Euroleon nostras (Fourcroy, 1785) - 1992. 04.

12. 2 lárva

Creoleon plumbeus (Olivier, 1811) - 1990. 06.

20. 5ơ 5\% ; 1992. 07.08. 10' 1999.07. 31. 10

A mintavételezések során begyüjtött anyag sem kvantitativ, sem kvalitatív értelemben nem gazdag. Ennek oka, hogy a természetvédelmi területen az erősen higrofil fátlan élöhelyeken - a többnyire meleg- és szárazságkedvelő Neuropteroidea fajok- nagyon gyér példányszámban kerültek elő. A Neuropteroidea fauna alacsony diverzitási értékét okozza még, hogy a területen kevés az öshonos fás vegetáció, amelynek zöme egyébként fiatal telepítésü. A Dunántúli-dombságon a Neuropteroidea fauna alapvetően a fás vegetációjú helyekhez kötödik. Az alföldi füves pusztákra jellemző sajátos és gazdag Neuropteroidea fauna a terület másodlagosan homokpusztává válása után sem itt, sem Belső-Somogyban nem tudott megtelepedni (ÁBRAHÁM 1992, 1995, 1998, 2001). A Látrányi Puszta Természetvédelmi Terület Neuropteroidea faunájának jellegzetességét azonban épp a speciális homokhoz kötődő élőhelyek (homokhátak stb.) határozzák meg.

A védett területen 6 különböző élöhelyet vizsgáltam, amelyek közül kettőből nem sikerült jellemző karakterfajt kimutatni.

(1) mocsár- és láprétek

A mocsár- és láprétek a védett területnek természetvédelmi szempontból egyik legértékesebb részét képezik. Ehhez az élöhelyhez azonban, a korábbi vizsgálatainkhoz hasonlóan (ÁBRAHÁM 1995, 1998), most sem sikerült a Neuroptera faunából jellemző fajt kapcsolni.

Ezen az élőhelyen a Neuropteroidea faunában a széles körben elterjedt gyakori fajok fordulnak csak elö.

(2) patakmenti füzesek

A jelenlegi kutatottsági szint mellett szintén nem sikerült a patakmenti füzesekre jellemző, hazánkban ritkának nevezhető fajt kimutatni. A védett terület határán ez az élőhelytípus csak egy-egy kis foltban - főleg a Tetves-patak mentén - taláható.

(3) vízi élöhelyek

A Tetves-patak egy rövid szakaszon érinti a védett területet. Ez, mint vízi élöhely erösen másodlagos, hisz itt a patak szabályozott, annak mentén hordaléklerakó csapdákat építettek. A Neuropteroidea fajok közül a Sialidae, a Sisyridae, Osmylidae család lárva- 
inak fejlődése vízhez kötődik. Azonban ezek közül csupán a legközönségesebb fajt a Sialis lutaria-t sikerült innen mindezidáig kimutatni.

(4) mezo-higrofil erdőfoltok

A mezo-higrofil erdei élőhelyhez a védett terület nyugati részén található, kis területre korlátozodó, fiatal, de természetközeli tölgyes - égeres foltok sorolhatók.

Ezek faunája valószínüleg a jelenleg kimutatott fajszámnál még gazdagabb, de kiterjedésük olyan kis foltra korlátozódik, hogy még több faj kimutatásához sokkal intenzívebb terepi munkára lenne szükség. Az élöhely jellemző fajai: Hemerobius humulinus, Chrysotopia ciliata, Dichochrysa prasina, Dichochrysa ventralis, Semidalis aleyrodiformis.

(5) xerofil homoki gyepek

A Látrányi Puszta Természetvédelmi Terület kb. felét részben xerofil homoki gyepek foglalják el. A védett terület $D$-i része nem legeltetett, míg az É-i része legeltetett. Ennek megfelelően a nem zavart $\mathrm{D}$-i rész fajgazdagabb.

Szinte egész Somogy területére jellemző psammofil fajok mindegyike megtalálható itt: Chrysopa abbreviata, Chrysopa commata, Creoleon plumbeus, Myrmeleon inconspicuus, Myrmeleon formicarius, Euroleon nostras.

Az első négy faj a nyílt homokhátakhoz kötődik. Az utolsó két hangyaleső faj lárvája pedig a zavart homokfelszínek, partfalak esőtől, széltől és közvetlen napsütéstől védett helyein fejlödik.

A Myrmeleon formicarius védett faj. Hazai elterjedési adatai főleg a domb- és hegyvidéki területekre esnek, ezért látrányi előfordulása figyelemre méltó.

A Chrysopa commata a zöld fátyolkák között nem nevezhető gyakorinak. A fajt hazánkból írták le a hatvanas évek végén. A környező országokban már mindenhol a védett vagy a vörös könyves listákon szerepel, így hazai vonatkozásban is nagyobb figyelmet érdemel jelenléte.

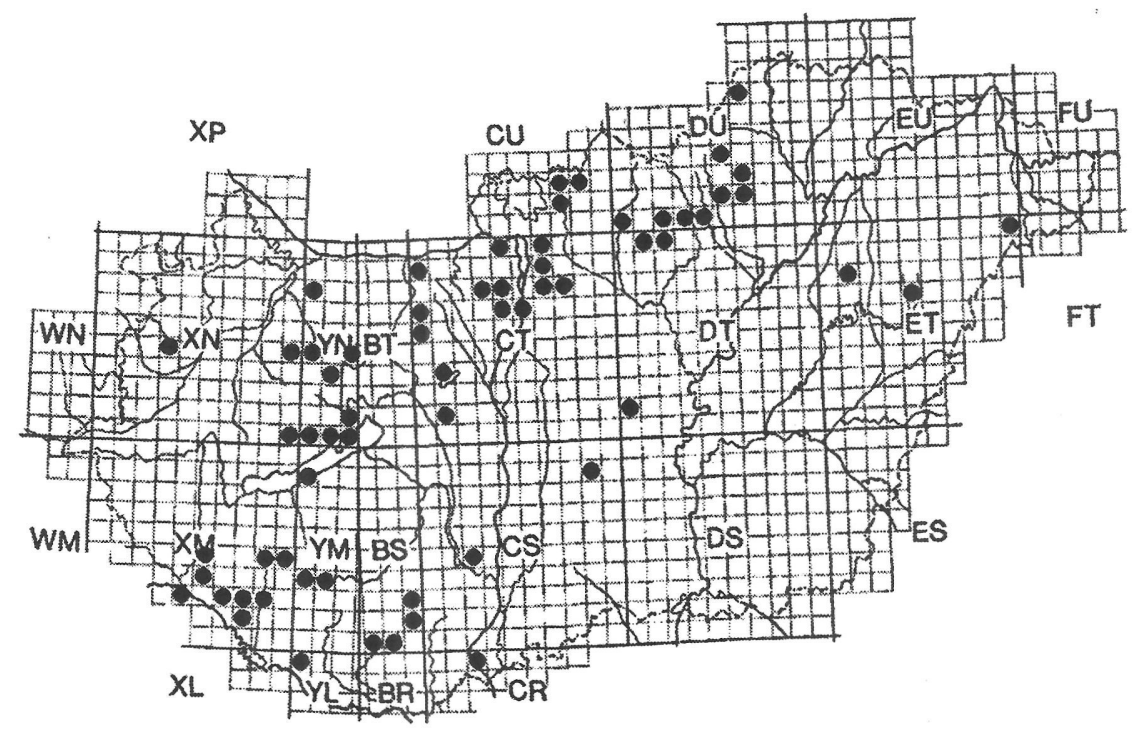

1. ábra: A védett közönséges hangyaleső (Myrmeleon formicarius) hazai elterjedése 
A Creoleon plumbeus és Myrmeleon inconspicuus hangyaleső fajoknak - a homok fedte Belső-Somogyban is - lokális az előfordulásuk, ezért minden élöhelyük megérdemelné a védelmet. Ezt a típusú élöhelyet foglalják el itt részben a telepített erdei fenyvesek is.

(6) ültetett erdei fenyvesek

Az ültetett erdei fenyvesek Neuroptera faunája szegényes, négy jellemző fajt sikerült innen kimutatnunk, melyek a fenyőtelepítésekkel országos viszonylatban is terjedő félben vannak (Coniopteryx pygmaea, Hemerobius nitidulus, Hemerobius stigma, Chrysopa dorsalis).

\section{Természetvédelmi megjegyzések}

A Neuroptera fauna igényeit figyelembe véve a védett területen lévő xerofil homoki gyepek kezeléséhez tudtunk helyi megfigyelési tapasztalatokat gyüjteni.

A területen a jelenlegi kezelés szempontjából két élöhelytípus található a homoki gyepekben.

A védett terület É-i része kezelt, ami azt jelenti, hogy a homoki gyepet szarvasmarhákkal legeltetik. Itt a kezelés hatására a gyep több helyen mozaikossá vált, ami a növényzet által fedett és nyílt homokfelszínek különböző mértékü váltakozását jelenti. Ez a szerkezet elvileg kedvez a védett fajok megtelepedésének és fennmaradásának, mivel a homokhoz kötődő Neuroptera fajok - különösen a hangyalesők - a homoki gyep állandó zavarását, bolygatását igénylik. Sajnos azonban úgy tünik, hogy a megfelelő szerkezetủ élőhelyfolt ellenére a populációk mégsem nagyok mivel a terület túllegeltetett. Homoki gyepekben egyébként sem szokás szarvasmarhát tartani! Valószínüleg a birka tartása kedvezőbb szerkezetüvé tenné a homokhátakon kialakult xerofil élőhelyet.

A nem kezelt homoki gyepfoltok a védett terület D-i részén találhatók.

Itt a vegetáció csodálatos. Azonban a kezelés hiányában már elörehaladott a homokhátakon a mozaikos szerkezetű gyepek záródása. A borítottság növekedése nem kedvező a hangyaleső fajok számára, mivel a gyep záródásával csökken a tölcsérépítésre alkalmas helyek száma. Kezelés nélkül a záródás feltételezhetően annak a következménye, hogy a terület magasabb csapadékmennyiséget kap, mint a kiskunsági hasonló élőhelyek. A kezelés hiányában viszont valószínüleg a terület klímazonális növénytársulásainak megfelelő szukcessziós fázisok alakulnak ki.

Ez a homoklakó fajok számára kedvezőtlen, pl.: hangyalesők, bizonyos fullánkos hártyásszárnyúak, cserebogárfélék stb., mig más csoportok, fajok számára a kialakult magas füvü homoki gyep vegetációszerkezete kifejezetten kedvező, pl.: néhány ritka lepkefaj.

Érdemes lenne a területen a kezelt és kezeletlen területek faunájában bekövetkezö változásokat néhány évig nyomon követni, hogy pontosabb információkkal rendelkezzünk a gyepek szerkezeti változása következtében bekövetkező faunaváltozásokról. Ezeket a vizsgálatokat, a Lepidoptera, Myrmeleontidae, Hymenoptera, Coleoptera bizonyos családjai és az Orthoptera csoportok által lehetne megnyugtatóan tisztázni. 


\section{Irodalom}

AsPöck H., AsPöck, U., Hölzel H. (unter Mitarbeit von H. Rausch) 1980: Dic Neuropteren Europas. Eine zusammenfassende Darstellung der Systematik, Ökologic und Chorologie der Neuropteroidea (Megaloptera, Raphidioptera, Planipennia) Europas 2 vols, 495\&355pp. Goccke\&Evers, Krefeld, F.R.G.

ASPÖCK H. HÖlZEL H. ASPÖCK U. 2001: Kommentier Katalog der Neuropterida (Insecta: Raphidioptera, Megaloptera, Neuroptera) der Westpalaarktis - Denesia 02 pp.1-606.

ÁBRAHÁM L. 1992: A Boronka - melléki Tájvédelmi Körzet nagyszárnyú, tevenyakú és recésszárnyú faunájának természetvédelmi értékelése (Megaloptera, Raphidioptera, Neuroptera) - Dunántúli Dolg. Term. Tud. Sor. 7: 107-125.

ÁBRAHÁM L. 1995: A tervezett Duna-Dráva Nemzeti Park recésszárnyú alkatú (Megaloptera, Raphidioptera, Neuroptera) faunájának természetvédelmi vizsgálata I. Dunántúli Dolg. Term. Tud. Sor. 8: 58-70.

ÁBRAHÁM L. 1998: Natural protection studies on the neuropteroids (Megaloptera, Raphidioptera, Neuroptera) fauna of the Duna-Dráva National Park, II. - Dunántúli Dolg. Term. Tud. Sor. 9: 269-289.

ÁBRAHÁM L. 2001: Somogy megye recésszárnyú-alkatúinak katalógusa - Natura Somogyiensis 1: 253-260.

\section{The neuropterid fauna of the Látrányi Puszta Nature Conservation Area (Megaloptera, Raphidioptera, Neuroptera)}

\section{LEVENTE ÁBRAHÁM}

In the course of 1999 and 2001, a faunistical survey of the Látrányi Puszta Nature Conservation Area was carried out focusing on Neuropteroida, beside other insect groups.

Samplings were collected by netting technique, light personally and by portable light traps in 6 different habitats, such as, riverine willow woods, wet habitats, meso-higrofil wood patches, xerophil sandy grasslands and on pine plantation. Altogether 434 specimens belonging to 1 Megaloptara, 1 Raphidioptera, and 35 Neuroptera species were collected. Among the habitats, only the fauna of the sandy grassland shows special characteristic. The following species are worth mentioning: (Chrysopa abbreviata, Chrysopa commata, Creoleon plumbeus, Myrmeleon inconspicuus, Euroleon nostras). In the nature conservation area, only one protected species was recorded: Myrmeleon formicarius.

Most of the lacewings in Hungary are associated with deciduous forest. Since this kind of habitat is rather small in distribution within the protected area, these species were found here in low abundance. The fauna of the isolated xerophil sandy grasslands, far away from the great sandy stretches of Hungary, is also poor in species. As succession continues, species associated with open sandy habitats show lower diversity from the point of view of nature protection. These require a steady disturbance of the xerophil sandy grassland. 